\title{
A 3-D shear velocity model of the southern North American and Caribbean plates from ambient noise and earthquake tomography
}

\author{
B. Gaite ${ }^{1}$, A. Villaseñor ${ }^{1}$, A. Iglesias ${ }^{2}$, M. Herraiz ${ }^{3,4}$, and I. Jiménez-Munt ${ }^{1}$ \\ ${ }^{1}$ Institute of Earth Sciences Jaume Almera, ICTJA-CSIC, Lluis Sole i Sabaris s/n, 08028 Barcelona, Spain \\ ${ }^{2}$ Institute of Geophysics, Universidad Nacional Autónoma de México, Mexico City, Mexico \\ ${ }^{3}$ Department of Geophysics and Meteorology, Universidad Complutense de Madrid, Madrid, Spain \\ ${ }^{4}$ Institute of Geosciences (UCM, CSIC), Madrid, Spain \\ Correspondence to: B. Gaite (bgaite@ictja.csic.es)
}

Received: 25 August 2014 - Published in Solid Earth Discuss.: 13 October 2014

Revised: 28 December 2014 - Accepted: 29 January 2015 - Published: 20 February 2015

\begin{abstract}
We use group velocities from earthquake tomography together with group and phase velocities from ambient noise tomography (ANT) of Rayleigh waves to invert for the 3-D shear-wave velocity structure $(5-70 \mathrm{~km})$ of the Caribbean (CAR) and southern North American (NAM) plates. The lithospheric model proposed offers a complete image of the crust and uppermost-mantle with imprints of the tectonic evolution. One of the most striking features inferred is the main role of the Ouachita-Marathon-Sonora orogeny front on the crustal seismic structure of the NAM plate. A new imaged feature is the low crustal velocities along the USA-Mexico border. The model also shows a break of the east-west mantle velocity dichotomy of the NAM and CAR plates beneath the Isthmus of the Tehuantepec and the Yucatan Block. High upper-mantle velocities along the Mesoamerican Subduction Zone coincide with inactive volcanic areas while the lowest velocities correspond to active volcanic arcs and thin lithospheric mantle regions.
\end{abstract}

\section{Introduction}

Crustal seismic models are important for several reasons. The first is the significant impact that crustal corrections have in mantle tomography (Bozdağ and Trampert, 2008; Lekić et al., 2010; Panning et al., 2010). Another is the strong dependency of earthquake location accuracy on the crustal velocity model.

Surface-wave earthquake-based global and regional tomography usually uses long period velocity measurements
( $T \geq 20 \mathrm{~s}$ ), sensitive to the lower crust and mantle structure. On the contrary, surface-wave local tomography constrains the upper-crustal seismic structure in narrow regions. Therefore there is a gap in imaging the whole crust at a continental scale with surface waves generated by earthquakes or active sources. Ambient noise tomography (ANT) overcomes this problem (e.g., Sabra et al., 2005; Shapiro et al., 2005) and has been applied to obtain crustal shear velocity models in different tectonic regions (e.g., Bensen et al., 2009; Zheng et al., 2011). Also, the increasing number of broadband seismic station deployments in the last decade has facilitated a higher path density.

Recent global shear wave velocity models from surface waves image the crust and uppermost mantle with $2^{\circ}$ or $1^{\circ}$ resolution (e.g., Shapiro and Ritzwoller, 2002; Pasyanos et al., 2013; Schaeffer and Levedev, 2013; Auer et al., 2014). In the area of this study, there are some regional and continental mantle seismic models from earthquake tomography (e.g., Vdovin et al., 1999; Godey et al., 2003; Schaeffer and Lebedev, 2014) that cover Mexico, the Gulf of Mexico (GOM), and part of the Caribbean. There have also been several localscale crustal structure studies (e.g., Campillo et al., 1996; Shapiro et al., 1997; Iglesias et al., 2010). Despite this, the seismic structure of the upper-crust of the whole region is not well defined from surface waves. One way to widen the period range to constrain the seismic structure from the crust to the mantle is to combine phase velocity from ANT and earthquake tomography (e.g., Yang and Ritzwoller, 2008; Yao et al., 2008; Zhou et al., 2012; Córdoba-Montiel et al., 2014). In this study we combine Rayleigh-wave group velocity from 


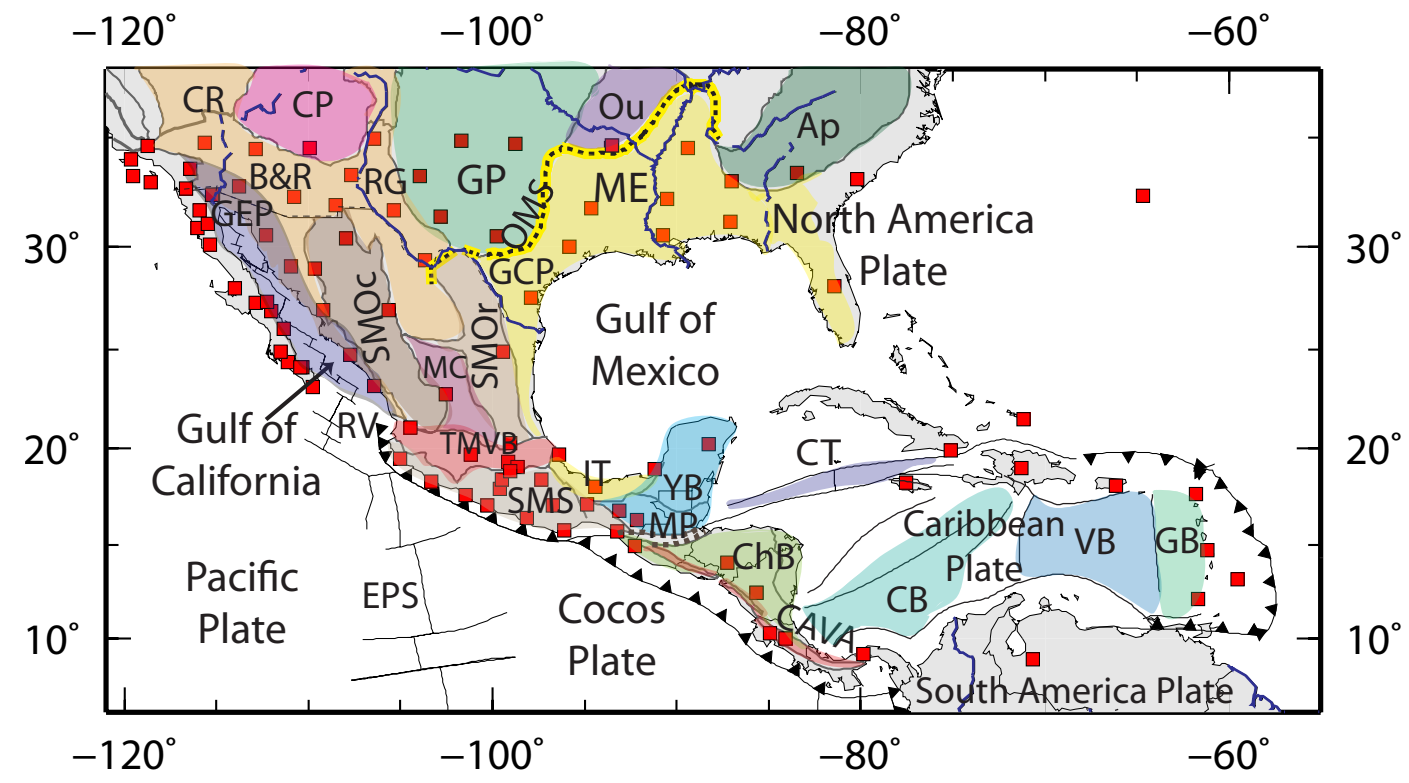

Figure 1. Simplified tectonic map of the study area: physiographic provinces shown as gray lines (Sedlock, 1993; M. Moschetti, personal communication, 2011; Marshall, 2007); stations as red squares; and plate boundaries as black lines (Bird, 2003). Ap denotes Appalachian Plateau Province; B\&R Basin and Range; CAVA Central America Volcanic Arc; CB Colombian Basin; ChB Chortis Block; CP Colorado Plateau; CR Colorado River; CT Cayman Trough; EPS East Pacific Rise; GB Grenada Basin; GCP Gulf Coastal Plain; GEP Gulf Extensional Province; GP Great Plains; IT Isthmus of Tehuantepec; ME Mississippi Embayment; MC Mesa Central; MP Motagua-Polochic fault system; Ou Ouachita Province; RG Rio Grande; RV Rivera Plate; SMOc Sierra Madre Occidental; SMOr Sierra Madre Oriental; SMS Sierra Madre del Sur; TMVB Trans-Mexican Volcanic Belt; VB Venezuela Basin; and YB Yucatan Block. Blue lines indicate main rivers. Highlighted yellow dashed black line indicates the Ouachita-Marathon-Sonora orogenic belt (OMS). Its extension into Mexico is taken from Handschy et al. (1987). The GEP location is taken from Zhang et al. (2007).

earthquake tomography and ANT to obtain short periods to constrain the lower-crust seismic structure. The final objective is to obtain a crust and uppermost-mantle vertically polarized shear-wave velocity model to image the area as a whole. To achieve this goal we invert Rayleigh-wave phase velocity from ANT simultaneously with group velocity combined from ANT and earthquake tomography in Mexico, the Gulf of Mexico, and the Caribbean.

\section{Data}

The data set used in this study consists of continuous recordings from nearly 100 broadband seismic stations of the Mexican and US national networks, other global and regional networks, and temporary deployments. One of the most important contributions of this study comes from the increased station coverage in the region since the beginning of the 21st century. The Mexican broadband National Seismic Network (IG) has expanded its coverage towards the north and the south of the country; the regional Caltech network (CI) has increased the coverage in California; and the deployment of the U.S. Geological Survey (USGS) Caribbean Network (McNamara et al., 2006) has significantly improved the station coverage in the Caribbean. The availability of data from several high-density temporal broadband networks, such as the NARS array in Baja California (Trampert et al., 2003) and the USArray Transportable Array in the continental US, has also increased the station density in the western and northern boundaries of the region. Figure 1 shows the distribution of the 103 broadband stations used in this study superimposed on a map showing the main tectonic features and physiographic provinces of the area. We analyze 117 earthquakes of $M \geq 5.5$, shallower than $40 \mathrm{~km}$ depth, and with epicenter-to-station path lengths ranging from hundreds to less than $10000 \mathrm{~km}$ (Fig. 2).

\section{Methods}

\subsection{Earthquake tomography}

We determine fundamental mode Rayleigh-wave group velocity dispersion curves from the earthquake records applying FTAN (Frequency Time ANalysis) with the PGSWMFA program from Ammon (1998). We invert these group velocity measurements to obtain 2-D group velocity models by the method of Barmin et al. (2001). This inversion procedure attempts to minimize a penalty function (Eq. (15) of Barmin et al., 2001) that depends on three damping parameters. These parameters are: $\alpha$ the data misfit damping, $\sigma$ the width of the Gaussian kernel and $\beta$ the penalty parameter to low path den- 

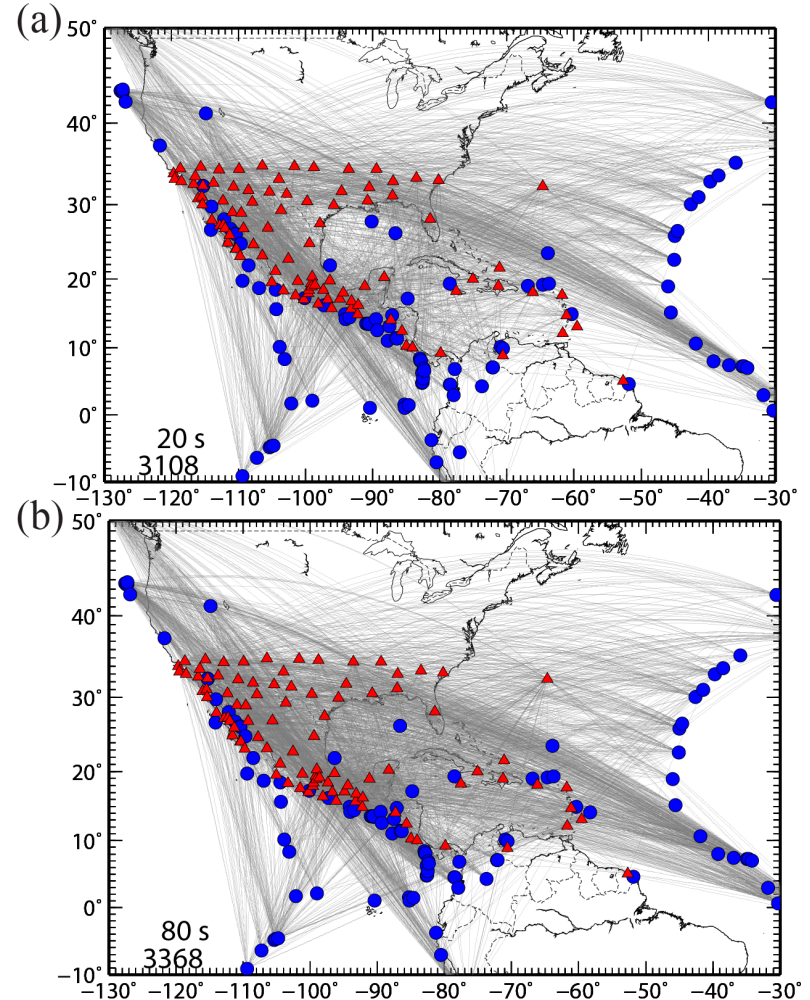

Figure 2. Path distribution of Rayleigh-wave group velocities at (a) $20 \mathrm{~s}$ and (b) $80 \mathrm{~s}$ period. Red triangles denote broadband seismic station locations and blue circles the earthquake epicenters. The number on each map indicates the number of paths.

sity regions. We perform a large number of inversions varying the value of the damping parameters. We test $\alpha$ values from 650 to 2000 combined with different values of $\sigma$ (from 100 to 500 ) and $\beta$ (from 1 to 100 ). The final values used are selected as a compromise between good data fit, stability of the features of the computed models and small model roughness. We follow a two-step tomographic inversion similar to the one described in Gaite et al. (2012). At each step we select the damping parameters. In the first step, we invert all the dispersion curves to obtain dispersion maps with damping parameters $\alpha=2000, \sigma=400$ and $\beta=1$. In the second, we remove outliers and re-invert the remaining data, in this case with $\alpha=1000, \sigma=500$ and $\beta=1$. We mark an observation as outlier when:

$\delta t>3(\mathrm{SD})$,

where $\delta t$ is the travel time residual, and SD is the standard deviation. The percentage of rejected outliers lies around $0.8 \%$ of the initial selection. Figure 2 shows the path coverage at 20 and 80 s periods. Mexico, the GOM and the western part of the Caribbean plate are well covered across all periods, whereas the eastern part of the Caribbean plate is well covered for periods longer than $20 \mathrm{~s}$.
From this second step we obtain group velocity maps for periods from 20 to $100 \mathrm{~s}$ on a $1^{\circ} \times 1^{\circ}$ grid (Fig. 3). The tomographic inversion used is similar to a Gaussian beam method and considers propagation of "fat" rays along the great circle. Following this, the frequency-dependent spatial sensitivity of the surface waves is described by Gaussian lateral sensitivity kernels. These kernels help to provide an accurate estimate of spatial resolution. To compute the spatial resolution we follow the method described by Barmin et al. (2001) with modifications of Levshin et al. (2005). Firstly, we construct a resolution kernel at each node of the model grid, which is a row of the resolution matrix. Secondly, we fit this kernel with a 2-D Gaussian function. Finally we compute the scalar spatial resolution as twice the standard deviation of the Gaussian. We obtain a spatial resolution of the group velocity maps less than or equal to $200 \mathrm{~km}$ for periods from 20 to $100 \mathrm{~s}$ in the whole area of interest (Fig. 4). This value is lower than twice the distance between the model grid points $\left(1^{\circ}\right)$. This means that the minimum spatial resolution we can obtain is $2^{\circ}$ and is limited by the distance between the nodes of the grid. Only at the edges of the inverted area do we obtain a $500 \mathrm{~km}$ spatial resolution.

\subsection{Ambient noise tomography}

We use Rayleigh waves' group and phase velocity dispersion curves from 8 to $50 \mathrm{~s}$ obtained from ambient noise tomography on a $1^{\circ} \times 1^{\circ}$ grid with a resolution of $250 \mathrm{~km}$ in Mexico and its surrounding area from our previous study, Gaite et al. (2012). To compute ANT we used 2 and a half years of continuous vertical component seismic records from the same stations used in this study. Firstly, we computed 1-day long ambient noise cross-correlations between each station pair and stacked them along their available time period. Secondly, we measured phase and group velocity of the fundamental mode Rayleigh wave. Finally, we inverted the dispersion curves to obtain phase and group velocity maps with the same method used for earthquake records in this study. The path coverage at periods shorter than $20 \mathrm{~s}$ is mostly limited to mainland North America that is well covered from $10 \mathrm{~s}$.

\subsection{Combination of ANT and earthquake tomography}

We combine group velocity measurements from ambient noise and earthquake tomography on each node of a $1^{\circ} \times 1^{\circ}$ grid to obtain group velocities from 8 to $100 \mathrm{~s}$ period. We follow a similar method to that described by Yao et al. (2008) to combine the measurements. First, we select group velocity measurements with resolution better than $250 \mathrm{~km}$ from ANT and $500 \mathrm{~km}$ from earthquake tomography. After that, we compose the group velocity dispersion as:

$U=\left\{\begin{array}{l}U_{\mathrm{ANT}}, T<20 \mathrm{~s} \\ \left(U_{\mathrm{ANT}}+U_{\mathrm{eq}}\right) / 2,20 \mathrm{~s} \leq T<50, \text { if }\left|U_{\mathrm{ANT}}-U_{\mathrm{eq}}\right| \leq 0.2 \mathrm{~km} \mathrm{~s}^{-1} \\ U_{\mathrm{eq}}, 20 \mathrm{~s} \leq T<50 \mathrm{~s}, \text { if }\left|U_{\mathrm{ANT}}-U_{\mathrm{eq}}\right|>0.2 \mathrm{~km} \mathrm{~s}^{-1} \\ U_{\mathrm{eq}}, T \geq 50 \mathrm{~s}\end{array}\right.$ 
(a)

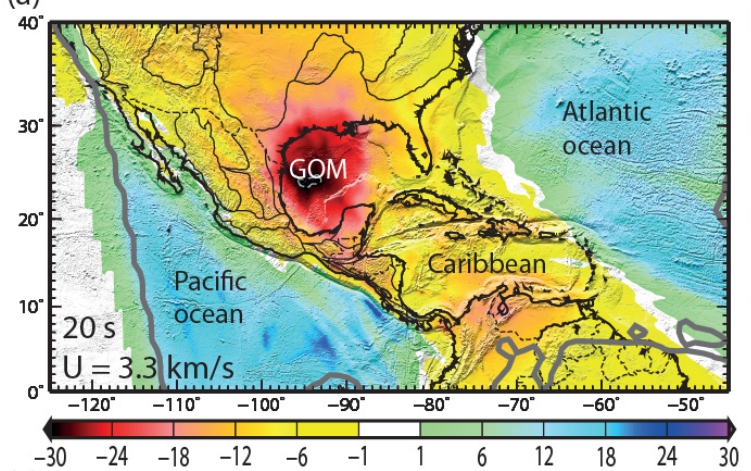

(c)

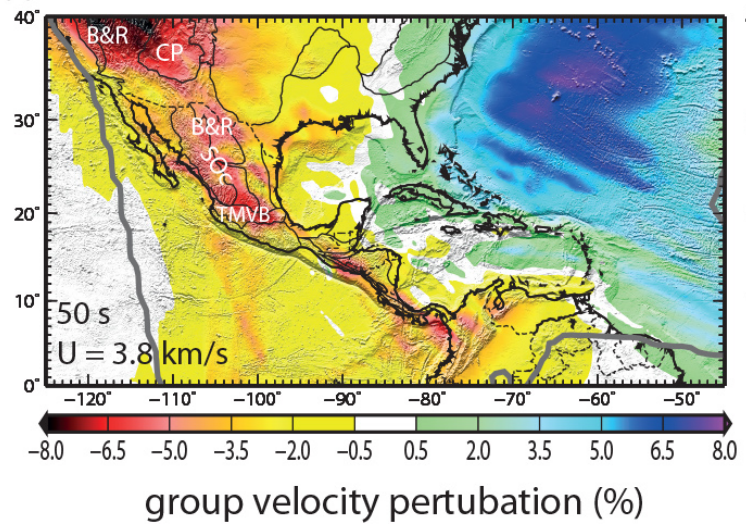

(b)

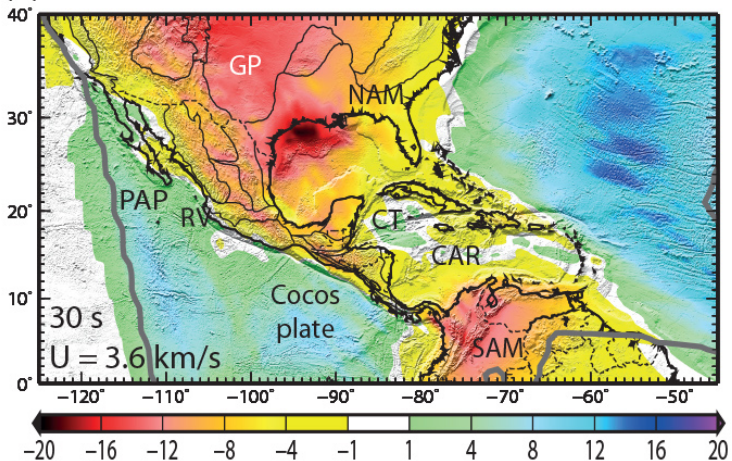

(d)

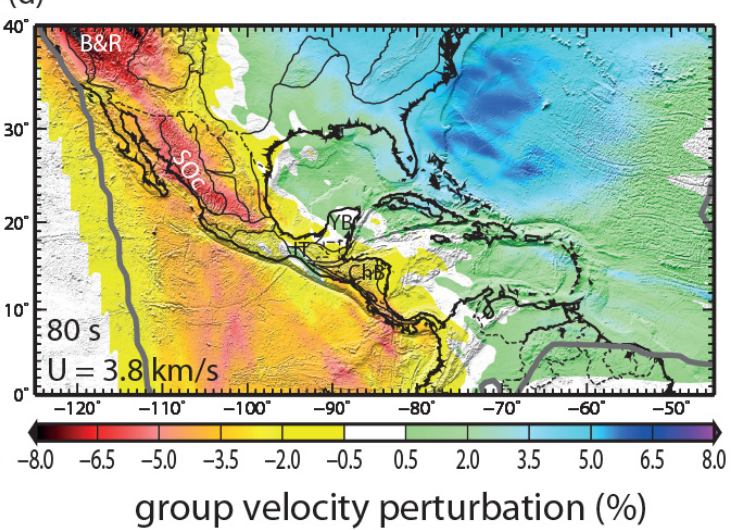

Figure 3. Rayleigh-wave group velocity perturbation maps at (a) 20, (b) 30, (c) 50, and (d) 80 s period. The velocity perturbation (\%) is computed with respect to the mean average velocity of the whole inversion area at each period and is indicated in each frame. Thick gray lines indicate the $450 \mathrm{~km}$ resolution contour and thin gray lines the tectonic provinces. B\&R denotes Basin and Range; ChB Chortis Block; CP Colorado Plateau; CT Cayman Trough; GOM Gulf of Mexico; GP Great Plains; IT Isthmus of Tehuantepec; NAM North American plate; PAP Pacific plate; RV Rivera plate; SAM South America plate; SMOc Sierra Madre Occidental; SMOr Sierra Madre Oriental; TMVB Trans-Mexican Volcanic Belt; and YB Yucatan Block.

where $T$ is the period and $U_{\mathrm{ANT}}$ and $U_{\mathrm{eq}}$ are the group velocities obtained for ANT and earthquake tomography, respectively (Fig. 5). The averaged difference between velocities obtained from ANT and from earthquakes varies from 0.09 to $1 \%$ in their common range of period (from 20 to $50 \mathrm{~s}$ ) (Fig. 6). This upper limit is slightly larger than in other studies $(\sim 0.1-0.5 \%)$ that compare phase velocity measurements (e.g., Lin et al., 2008; Yang and Ritzwoller, 2008; Yao et al., 2008; Ritzwoller et al., 2011; Zhou et al., 2012). Our larger difference might be due in part to the fact that we compare group instead of phase velocities. Phase velocity measurements are more stable than group velocities.

\subsection{Shear wave velocity model}

We simultaneously invert group and phase velocity measurements for a 1-D shear wave velocity structure at each grid point by using a simple parameterization of the medium consisting of 3 constant velocity layers over a half-space. The model parameters ( 4 velocities and 3 thicknesses) can vary across a wide range to obtain an optimized solution for the whole variety of tectonic domains in the study area. We consider the media as a Poisson solid, i.e.:

$\lambda=\mu \quad v=1 / 4$

where $\lambda$ and $\mu$ are the Lamé parameters and $v$ is the Poisson ratio. We determine the density as per Berteussen (1977):

$\rho=0.32 \cdot v_{\mathrm{p}}+0.77$

where $v_{\mathrm{p}}$ is the $\mathrm{P}$-wave velocity.

We use a modified code from Iglesias et al. (2001) to jointly invert phase and group velocities. This code solves the forward model with the subroutine SURFACE85 (Herrmann, 1987) and inverts with the simulated annealing algorithm (Goffe et al., 1994; Goffe, 1996). Simulated annealing is a global optimization method. The algorithm scans the possible solutions space to find the optimum model by reducing the searching vector length when it is close to a minimum and allowing misfit increases to avoid local minimums. The algorithm determines as the optimum model that which minimizes the misfit during a certain number of searching iterations. To assure the inversion of high quality dispersion 
(a)

(b) 40

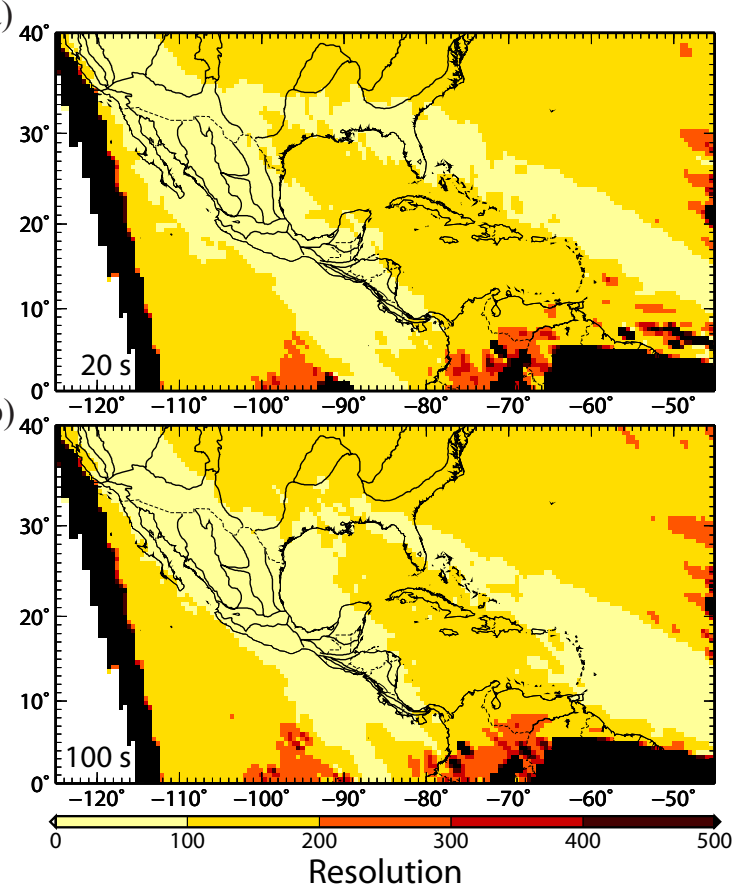

Figure 4. Estimated resolution in $\mathrm{km}$ for group velocity maps at (a) $20 \mathrm{~s}$ and (b) $100 \mathrm{~s}$ period.

curves, we only invert dispersion curves with velocity measurements at more than 3 discrete frequencies. By doing this we avoid inverting nodes with high resolution at narrow frequency ranges. We select as optimum models only those with velocity increasing with depth.

The misfit of the dispersion measurements is computed as:

misfit $=\left\{\begin{array}{l}0.5 \cdot e_{C}^{M}+1.5 \cdot e_{U}^{N} \text { if } M<N \\ e_{C}^{M}+e_{U}^{N} \text { if } M=N \\ 1.5 \cdot e_{C}^{M}+0.5 \cdot e_{U}^{N} \text { if } M>N\end{array}\right.$,

where $e_{C}^{M}$ and $e_{U}^{N}$ are the errors computed in a L2 sense for $\mathrm{M}$ phase and $\mathrm{N}$ group dispersion measurements, respectively. The mean misfit for all inverted nodes is $0.2 \mathrm{~km} \mathrm{~s}^{-1}$ (Fig. 7a). Figure $7 \mathrm{~b}$ shows the geographical distribution of the model misfit. The highest misfit values lay offshore, in regions with low path coverage and outside the area of interest in this work. The largest misfit values in the area of interest are on the easternmost part of the GOM and the Yucatan platform.

As the final step, we combine the 1-D shear models from each node to produce a 3-D shear wave velocity model.

\section{Results and discussion}

The 3-D shear-wave velocity model obtained from inverting Rayleigh-wave group velocities (10 to $100 \mathrm{~s}$ ) and phase velocities (10 to $50 \mathrm{~s}$ ) is sensitive to velocity changes from 5 down to $70 \mathrm{~km}$ depth. The inversion fits periods $\leq 80$ s better than the longer ones (Fig. 8). According to the procedure
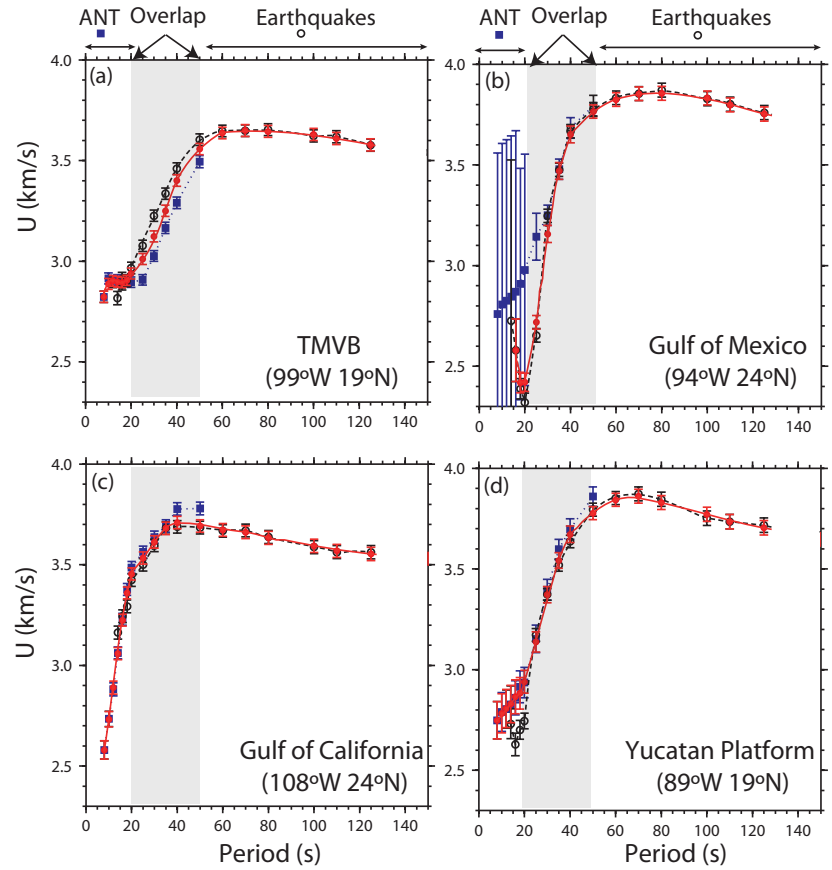

Figure 5. Examples of joining group velocity obtained from ANT (blue squares) and from earthquake tomography (empty circles) at four nodes of the inversion region representing different tectonic settings. The error bars denote resolution normalized by $2500 \mathrm{~km}$ at each period. The gray area limits the velocity overlapping and joining period range. Filled circles and continuous red lines indicate the combined dispersion curve.

described above, velocities at periods around $10 \mathrm{~s}$, sensitive to shallower portions of the crust, are obtained from ANT with equal or higher resolution than $250 \mathrm{~km}$. The short period dispersion results are obtained for the whole of Mexico and some parts of the CAR plate and the southern US (white contour in Fig. 9a). This means that the shear velocity model constrains the shallow crust of Mexico better than the crust of the GOM and the Caribbean plate. The lateral resolution of the model is about $220-250 \mathrm{~km}$ and comes from the spatial resolution of the surface-wave velocity maps. This model offers a crust and uppermost mantle image of the whole area. Its agreement with the main known tectonic characteristics and the recovery of the major crustal features obtained in previous local studies provides reliability on our results and the confidence to interpret them on regions with a lack of shearwave lithospheric information. The crustal and uppermostmantle seismic structure features revealed by the model correlate well with traces of different tectonic evolution stages of the region. Deeper insights on the kinematics and dynamics within this region might be obtained from azimuthal anisotropy. It is out of the current scope, but a natural extension of this research. 

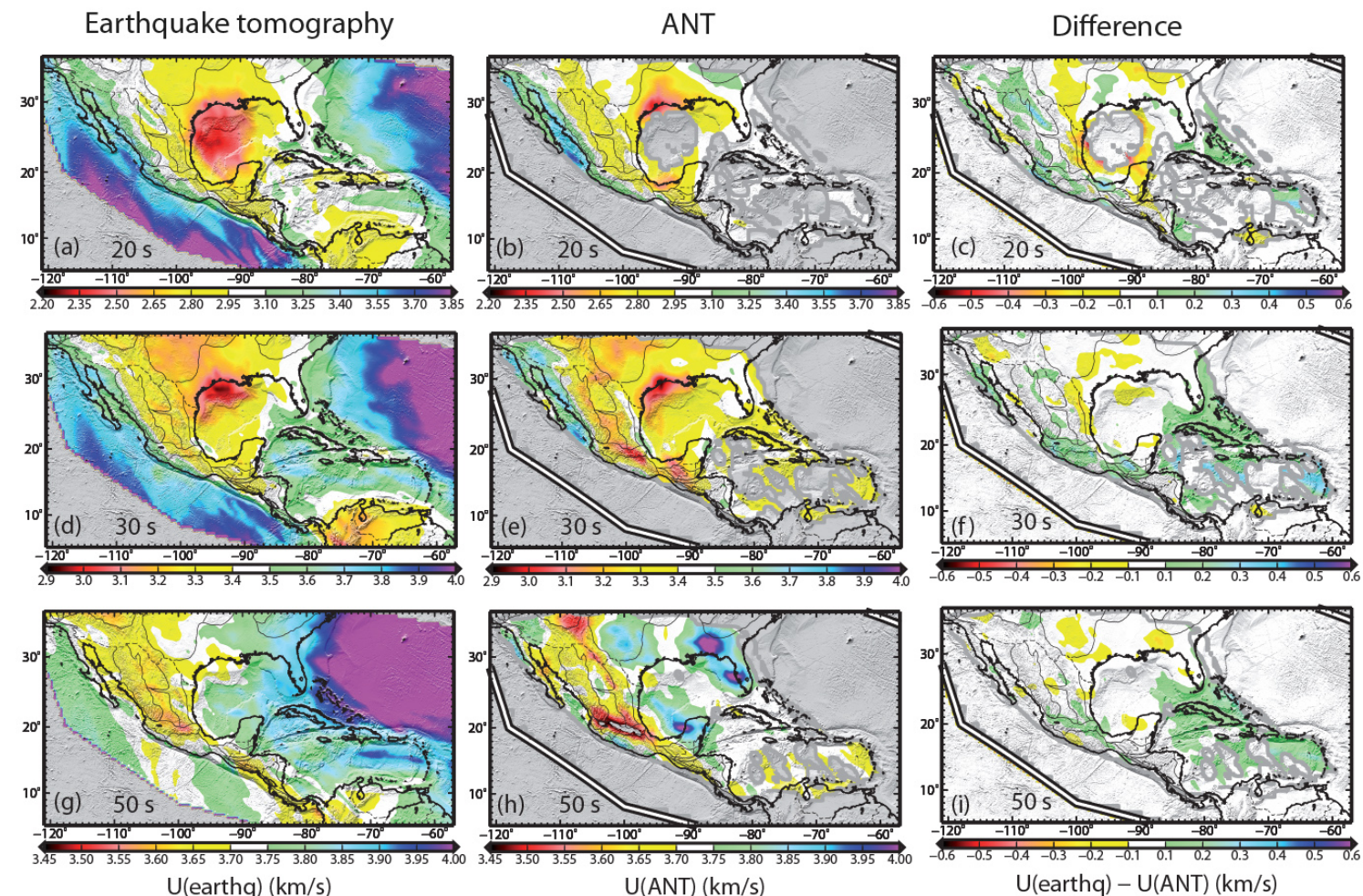

$\mathrm{U}(\mathrm{ANT})(\mathrm{km} / \mathrm{s})$

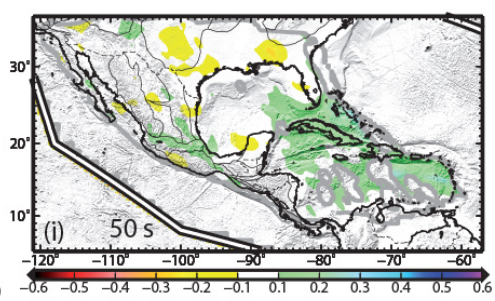

$\mathrm{U}($ earthq) $-\mathrm{U}(\mathrm{ANT})(\mathrm{km} / \mathrm{s})$

Figure 6. Rayleigh-wave group velocity maps from: earthquake tomography with resolution $\leq 500 \mathrm{~km}$ (a, d, g); ANT with resolution $\leq 250 \mathrm{~km}$ (b, e, h); and their difference in the common area (c, f, i) at 20, 30, and 50 s period. The white line outlined by black marks the ANT inversion area.

\subsection{Crust}

The model identifies different velocities between the Yucatan and Chortis continental blocks at $30 \mathrm{~km}$ depth (Fig. 9d). This seismological lower crustal difference agrees with the different origin and tectonic evolution proposed by several studies from geologic evidence and paleotectonic reconstructions (e.g., Burke, 1988; Rogers et al., 2007; Pindell and Kennan, 2009). It also reveals crustal heterogeneity on the Caribbean plate oceanic basins (Colombia, Venezuela, and Grenada) (Fig. 9c), despite the lower resolution of the model over this plate. The model also exhibits a high contrast between the upper and lower crustal velocities of the inland North American plate (Fig. 10).

\subsubsection{Basins and shallow basement}

Low upper-crust velocities (Fig. 9a) correspond to sedimentary basins along the Gulf Coastal Plain, the Gulf of California, the USA-Mexico border and the Motagua-Polochic fault system, while high velocities correlate with mountain ranges (e.g., the Sierra Madre Oriental, Sierra Madre Occidental, and Sierra Madre del Sur). These low velocities are observed down to approximately $5 \mathrm{~km}$ beneath the Gulf Coastal Plain, the Rio Grande drainage basin and the Colorado river mouth, but they reach down even further to $12 \mathrm{~km}$
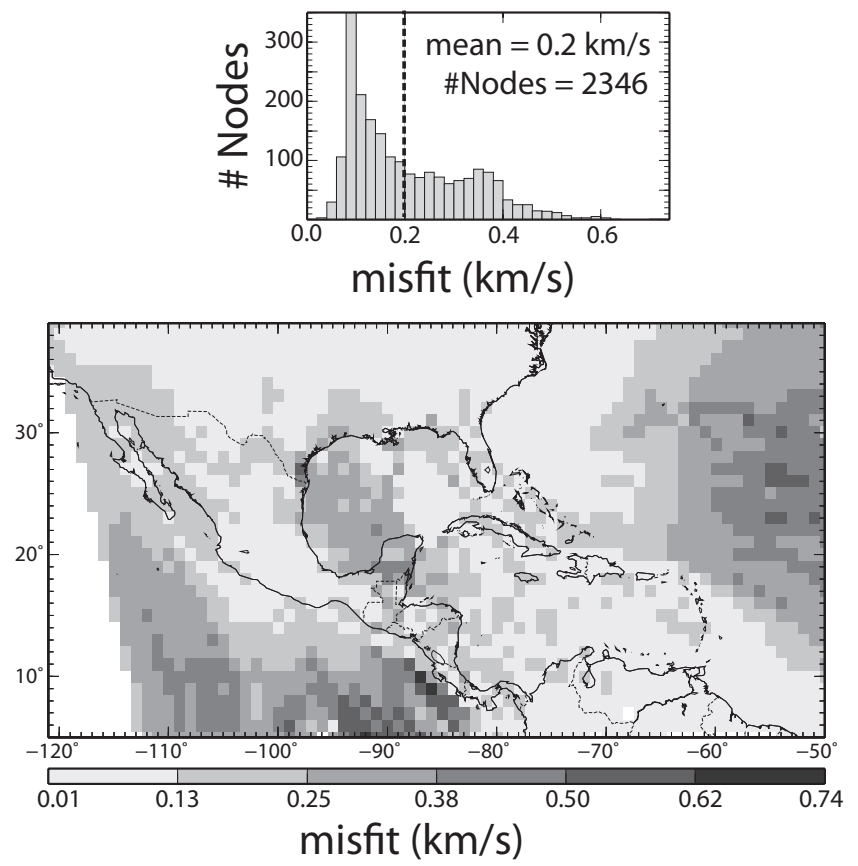

Figure 7. (a) Histogram and (b) map of the misfit of inverted dispersion curves at each node. 

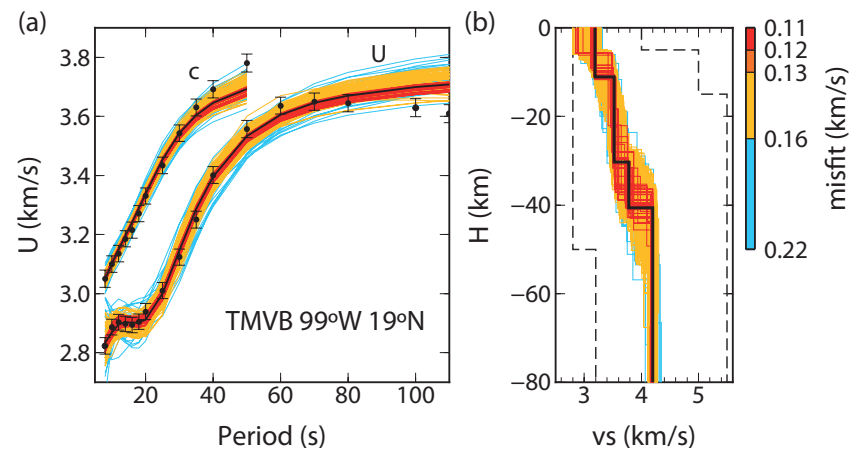

Figure 8. Example of 1-D inversion of phase and group velocity at one node of the grid situated on the TMVB. (a) Dispersion curves (group and phase) obtained from the combination of ANT and earthquake based tomography (circles). Their error bars are calculated as the resolution of the tomography on this node and period normalized by a factor of 2500 (in $\mathrm{km}$ ). Accepted models are shown as colored lines, and the best fitted dispersion curves as black lines. (b) Dashed lines show the feasible region in the inversion; the colored lines are the models with misfits less than or equal to two times the best fitting $\left(0.11 \mathrm{~km} \mathrm{~s}^{-1}\right)$; and the black line indicates the shearvelocity model that best fits the observed dispersion curves. The scale shows the color code of the misfit.

beneath the Mississippi embayment (Figs. 9a, b, 10a). This low velocity anomaly beneath the Mississippi embayment agrees well with the sediment thickness model of Laske et al. (2013) and the velocity model of Bensen et al. (2009). Our model also shows low velocities along the USA-Mexico border with the lowest values coincident with the Rio Grande drainage basin, the major Holocene coastal depocenter west of the Mississippi delta.

The Ouachita-Marathon-Sonora orogen is a $3000 \mathrm{~km}$ long belt of deformed Paleozoic rocks bordering the southern margin of the Laurentian (North American) craton (Moreno et al., 2000; Poole et al., 2005). The eastern part of this belt encloses low velocity areas beneath the Mississippi and Rio Grande embayment (Fig. 9a). The location of the southern Laurentia margin has been much debated (e.g., Moreno et al., 2000). Poole et al. (2005) localized it along Chihuahua, Sonora, and Baja California, but Dickinson (2009) considers it still a genuine frontier of geoscience. Our results at $12 \mathrm{~km}$ depth (Fig. 9b) show the highest inland velocities $(\sim 3.6-$ $3.74 \mathrm{~km} \mathrm{~s}^{-1}$ ) along the eastern and central margins of Laurentia, where the Appalachian and Ouachita orogens expose their rock assemblages. These velocities extend toward the west and south coinciding with the southern limit of the Great Plains and the north of Sierra Madre Oriental (SMOr), following the Ouachita-Marathon-Sonora orogen. This high crust velocity signature of the Laurentia margin is not distinguished further west in our model.

\subsubsection{Present and ancient crustal extension}

The extension in western North America during the late Oligocene to early Pliocene has evolved from the continental-scale Basin and Range Province, to a more limited region known as Gulf Extensional Province (GEP), and finally, the deformation has been limited to the west of the GEP forming the Gulf of California rift (Aragón-Arreola et al., 2005; and references therein). The marine incursion over the rift formed the Gulf of California (GofC). At present, the GofC hosts a zone of oblique extension that records the transition from oceanic spreading centers and transform faulting in the south (Londslade, 1989; Lizarralde et al., 2007) to the diffuse continental deformation in the north (Oskin and Stock, 2003; González-Fernández et al., 2005). We obtain a heterogeneous shear-wave velocity distribution along the GofC in accordance with its different tectonic stages and with results from several local studies (Aragón-Arreola and Martín-Barajas, 2007; Persaud et al., 2007; Wang et al., 2009; Zhang and Paulssen, 2012). Seismological data show a significant difference in crustal thickness between the Sierra Madre Occidental core and its margins. Several studies estimated the crustal thickness at the center of the Sierra Madre Occidental around 36-40 km (Gomberg et al., 1989; Couch et al., 1991). It thins towards the south and west to $25 \mathrm{~km}$ at the coast (Persaud et al., 2007) where the crust has been thinned by extension that led to the formation of the Gulf of California. Our model shows thinner crust beneath the GofC $(<20 \mathrm{~km})$ than in contiguous areas (Baja California Peninsula and SMOc). We obtain $\sim 30 \mathrm{~km}$ crustal thickness beneath the SMOc and it thickens toward the east to $\sim 35 \mathrm{~km}$ under SMOr (Fig. 10b). Crustal thickness differences under SMOc and SMOr between the results of this study and previous studies are within the range of our vertical resolution. Bouguer anomaly changes are the result of density variations at different depths. Negative anomalies are related to low densities, which at large scale can be due to large sediment basins, thick crust, or shallow asthenosphere. Positive Bouguer anomalies denote high density rocks and may be thin crust. Figure 11 shows the Bouguer gravity anomaly map for the study area. It has been computed applying a complete Bouguer correction to free-air satellite data (Sandwell and Smith, 1997) using the code FA2BOUG (Fullea et al., 2008) with a reduction density of $2670 \mathrm{~kg} \mathrm{~m}^{-3}$. The observed changes in crustal thickness between the SMOc core and its margins correlate well with the large negative Bouguer anomaly values at the center and less negative at its western part (Fig. 11).

One of the novelties of this velocity model is that it clearly draws the limits of the GEP province as high lower-crust velocities in contrast with low velocities in the surrounding areas. For example, at $25 \mathrm{~km}$ depth the contour between high $\left(>4.0 \mathrm{~km} \mathrm{~s}^{-1}\right)$ and low velocities $\left(<3.5 \mathrm{~km} \mathrm{~s}^{-1}\right)$ is narrow and sharp, indicating a limit between extended and unextended crust (Fig. 9c). Defining the GEP province like this, it 

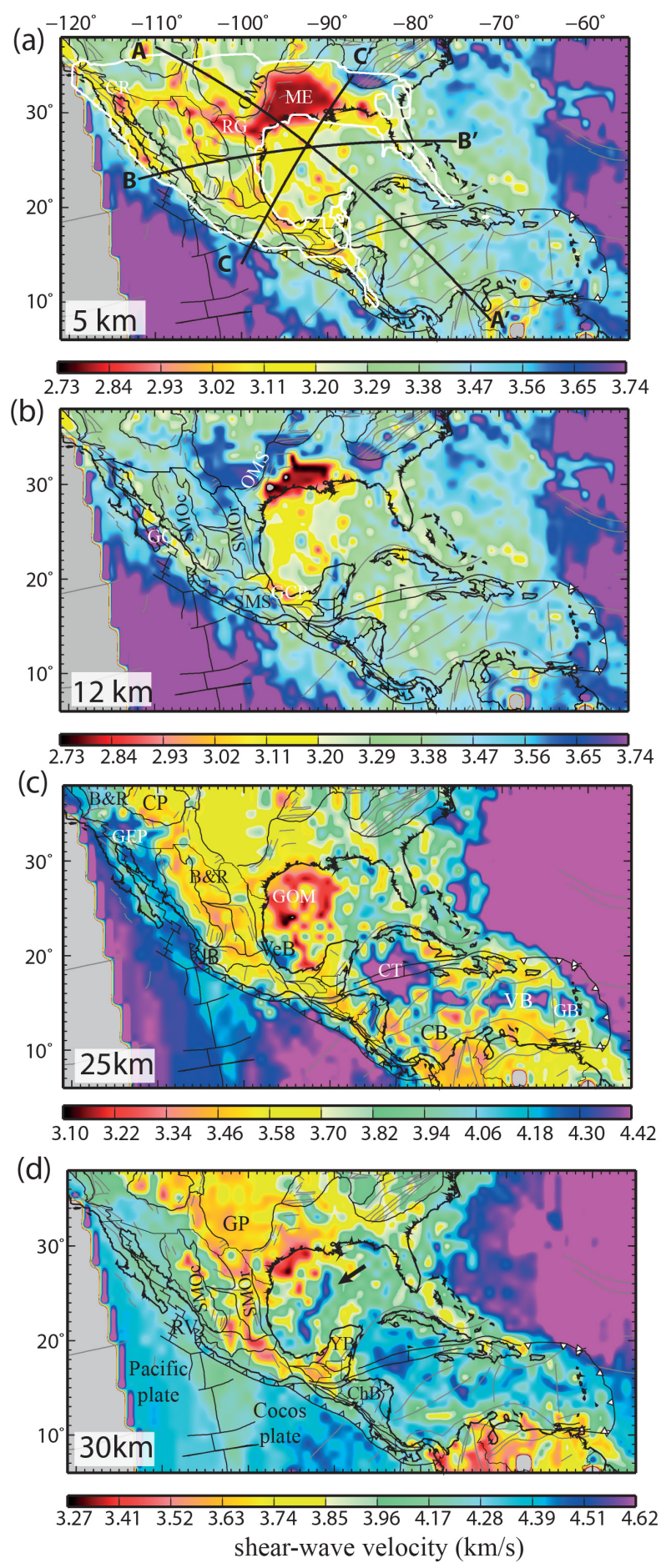

Figure 9. Shear wave velocity maps at different depths ((a) 5, (b) 12, (c) 25, and (d) $30 \mathrm{~km}$ ). Faults, ridges, fracture zones, and basin limits are denoted as gray lines (CGMW/UNESCO, 2000). (a) Thick black lines indicate the cross-sections shown in Fig. 10 and the white line contours the area with ANT resolution equal to or lower than $250 \mathrm{~km}$ at 10 s period. B\&R denotes Basin and Range; CB Colombian Basin; ChB Chortis Block; CP Colorado Plateau; CR Colorado River; CT Cayman Trough; GB Grenada Basin; GCP Gulf Coastal Plain; GEP Gulf Extensional Province; GOM Gulf of Mexico; GP Great Plains; IT Isthmus of Tehuantepec; JB Jalisco Block; ME Mississippi Embayment; OMS Ouachita-Marathon-Sonora orogenic belt; RG Rio Grande; RV Rivera Plate; SMOc Sierra Madre Occidental; SMOr Sierra Madre Oriental; SMS Sierra Madre del Sur; TMVB Trans-Mexican Volcanic Belt; VB Venezuela Basin; VeB Veracruz Basin; and YB Yucatan Block. 
(a)

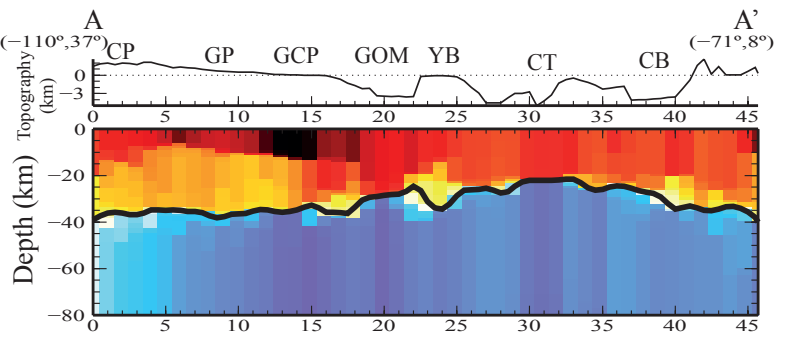

(b)

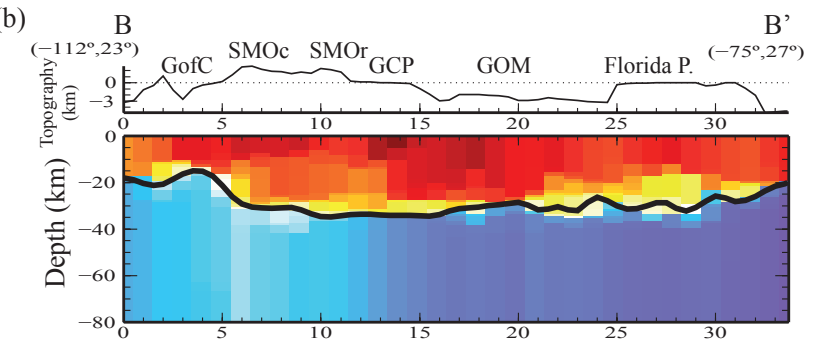

(c)

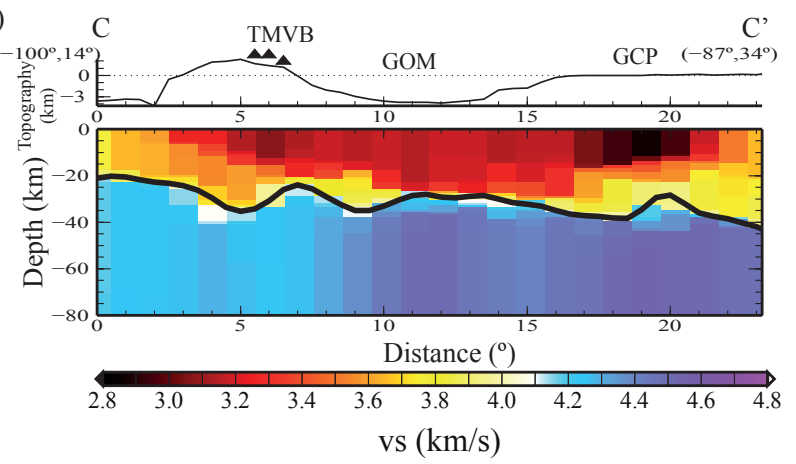

Figure 10. Shear wave velocity along the cross-sections delineated in Fig. 9; (a) A-A', (b) B-B', and (c) C-C'. The figure shows moho depth (thick black line), topography (thin black line above the velocity profile), and sea level (dashed line). CB denotes Colombian Basin; CP Colorado Plateau; CT Cayman Trough; Florida P. Florida Peninsula; GCP Gulf Coastal Plain; GofC Gulf of California; GOM Gulf of Mexico; GP Great Plains; SMOc Sierra Madre Occidental; SMOr Sierra Madre Oriental; TMVB Trans-Mexican Volcanic Belt; and YB Yucatan Block.

comprises the US B\&R and the western part of SMOc, where Ferrari et al. (2007) indicated a signature of the active extension related with the subduction of the Farallon plate under the NAM plate. We obtain a similar high velocity structure beneath the western part of the TMVB that coincides with the area enclosed by the triple graben (Luhr et al., 1985) on the Jalisco Block where the Rivera plate subducts. The thin crust observed in this area is evidence of an extension process, coherent with the proposed Jalisco Block rifting from the North American plate (Luhr et al., 1985; Allan et al., 1991). Another noteworthy feature is that our results highlight a different crustal seismic structure between the US and Mexican Basin and Range provinces.

Widely accepted Gulf of Mexico reconstruction models fit its opening from 158 to $130 \mathrm{Ma}$ (e.g., Pindell and Kennan, 2009). During the extension of the GOM, fragments de-
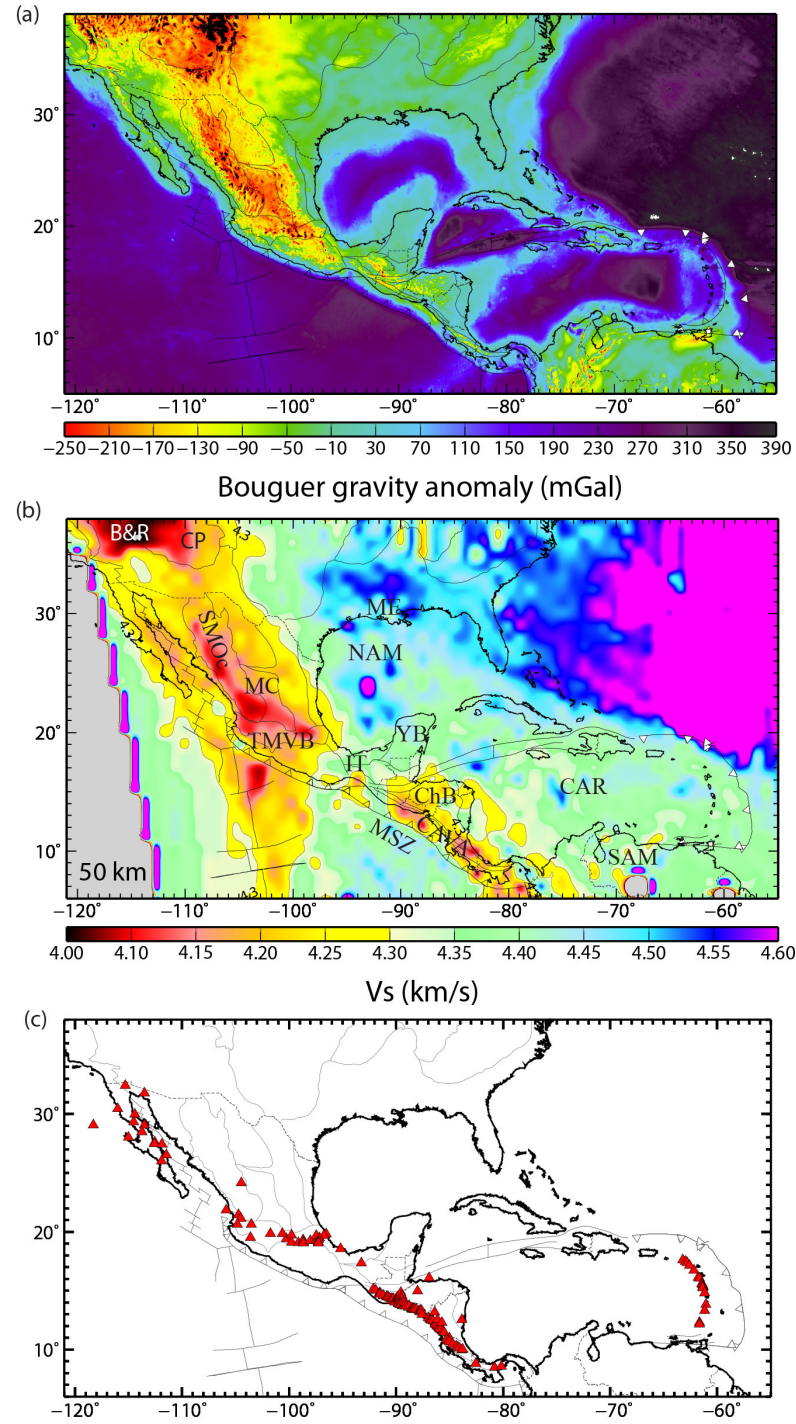

Figure 11. (a) Bouguer gravity anomaly map. (b) Shear wave velocity map at $50 \mathrm{~km}$ depth. (c) Map with the location of volcanoes (red triangles) exhibiting current unrest or eruptions during the Holocene (Siebert and Simkin, 2002). B\&R denotes Basin and Range; CAR Caribbean plate; CAVA Central America Volcanic Arc; ChB Chortis Block; CP Colorado Plateau; IT Isthmus of Tehuantepec; ME Mississippi Embayment; MSZ Mesoamerican Subduction Zone; NAM North American plate; SAM South American plate; SMOc Sierra Madre Occidental; TMVB Trans-Mexican Volcanic Belt; and YB Yucatan Block.

tached from NAM, migrating to the south, and forming the Yucatan Block and the northern portion of SAM plate. The GOM tectonic evolution comprises seafloor spreading, and Yucatan Block rifting and rotation (30-40 clockwise) from its origin location, attached to south-central US, to its present location. The GOM sediment seismic structure has been extensively explored for hydrocarbons and is well known; however, the underlying crust and mantle velocity distribution 
are still poorly understood (Swayer et al., 1991). Whole images of the GOM crustal seismic structure come from compilations of local-experiments (e.g., Swayer et al., 1991; Bird et al., 2005). Besides, the large basin's sediment thickness made deep-penetration observations difficult (Swayer et al., 1991). In fact, the short period ambient noise crosscorrelations from paths crossing the GOM had a very low signal-to-noise ratio (Gaite et al., 2012). Therefore, we define the GOM seismic structure from tomographic results of $20 \mathrm{~s}$ period and longer which means that its shallow crust shear wave velocity structure is not as well defined as in mainland North America. In spite of this limitation, our results show a sharp difference between crustal velocities west and east of $-90^{\circ}$ longitude (Fig. 9). Previous tomographic studies (e.g., Vdovin et al., 1999) associate low Rayleigh and Love wave group velocity at $20 \mathrm{~s}$ period on the western part of the GOM with a large accumulation of sediments. Our results confirm this correspondence: we find very low shear-wave velocities $\left(\sim 3.2 \mathrm{~km} \mathrm{~s}^{-1}\right)$ down to $20 \mathrm{~km}$ depth that coincide with the sediment thickness on the Gulf of Mexico reported by Divins (2003) from isopach maps, ocean drilling results, and seismic reflection profiles. We obtain an average crustal thickness beneath the GOM of $25-30 \mathrm{~km}$ that coincides with the results of Bird et al. (2005) from gravimetric data and a compilation of seismic reflection experiments in particular areas of the GOM. At $30 \mathrm{~km}$ depth our results show a narrow NNE high velocity area (Fig. 9d) indicating a thinner crust than at the rest of the GOM. This high velocity feature should be interpreted with caution because the lack of path coverage at periods shorter than $20 \mathrm{~s}$ to constrain the uppermost crust and the large misfits in the western GOM (Fig. 7). This feature might be related with the gulf opening during the Jurassic, since it matches with the youngest crust in the gulf (Müller et al., 2008) and roughly with the recent gravity results of Sandwell et al. (2014). However, its orientation does not coincide with the ENE direction of the extinct ridge proposed by Pindell and Kennan (2009), the results by Swayer et al. (1991), and with the GOM largest gravity anomalies by Bird et al. (2005).

Some local seismic experiments of receiver functions infer thin crust beneath the Veracruz Basin (e.g., Melgar and Pérez-Campos, 2011; Zamora-Camacho et al., 2010). Our results confirm these observations, revealing high velocities $\left(\sim 4.2 \mathrm{~km} \mathrm{~s}^{-1}\right)$ at $25 \mathrm{~km}$ depth offshore of the Veracruz Basin (Fig. 9c).

\subsection{Upper mantle}

Several tomographic continental-scale studies (e.g., Alsina et al., 1996; Van der Lee and Nolet, 1997; Vdovin et al., 1999; Godey et al., 2003; Bedle and van der Lee, 2009) image the dichotomy between the low mantle seismic velocities of the western North American and Caribbean plates and the high velocities of their eastern parts. Our model shows this velocity contrast from $50 \mathrm{~km}$ depth (Fig. 11) with great detail due to the large number of stations used in Mexico and the Caribbean. We find low shear-wave velocities in the western US, along Mexico and below the Chortis Block, and high velocities in the central-east US, the Gulf of Mexico, the Isthmus of Tehuantepec, the Yucatan Block, the central and eastern parts of the Caribbean plate, and on the northern South American plate. At $50 \mathrm{~km}$ depth, the $4.30 \mathrm{~km} \mathrm{~s}^{-1}$ velocity contour roughly follows the western boundary of the Great Plains, the northeast of the Sierra Madre Oriental, and the western part of the Gulf of Mexico toward the Isthmus of Tehuantepec. This contour resembles the $4.55 \mathrm{~km} \mathrm{~s}^{-1}$ velocity contour at $80 \mathrm{~km}$ depth obtained by Bensen et al. (2009), which lies close to the Rocky Mountain Front in the southern US. The west-east mantle dichotomy symmetry breaks beneath the eastern part of the Sierra Madre del Sur, the Isthmus of Tehuantepec, and the Yucatan Block, whose high velocities contrast with the lower ones of the surrounding areas. This symmetry break supports the aforementioned different origin of the Yucatan Block in comparison with the other Mexican terrains and the Chortis Block.

Along the Mesoamerican Subduction Zone high velocities at $50 \mathrm{~km}$ depth coincide with a lack of active volcanism in certain areas (e.g., south of Sierra Madre del Sur, part of the Isthmus of Tehuantepec), while low velocities correspond to active volcanic arcs (e.g., TMVB and CAVA). Regional and global seismic tomographic studies (Grand, 1994; Alsina et al., 1996; Van der Lee and Nolet, 1997; Bijwaard and Spakman, 2000; Ritzwoller et al., 2002; Ritsema et al., 2004) suggest that the lithospheric mantle has been mostly removed and replaced by asthenospheric mantle in the region between the Gulf of California and the Mesa Central, and from the US Basin and Range Province to latitude $20^{\circ} \mathrm{N}$. This is in agreement with the low velocities estimated at $50 \mathrm{~km}$ depth (Fig. 11). We also obtain low velocities along the Gulf of California oceanic ridge. Negative Bouguer gravity anomalies coincide with low shear-wave velocities at $50 \mathrm{~km}$ depth on the north of the Basin and Range, west of the Colorado Plateau and Mesa Central (Fig. 11). This coherence may be the effect of a thin lithosphere (e.g., B\&R, Colorado Plateau) or may support the presence of magmas from a mantle wedge below the Mesa Central crust inferred by Nieto-Samaniego et al. (2005). However, we did not find such a straightforward relation between negative Bouguer gravity anomalies and low mantle velocities in every region (for example, at the westernmost part of SMOc and TMVB). This different pattern on the gravity field may be due to the combination of the contrary effects of thin crust and thin lithospheric mantle. 


\section{Conclusions}

We invert group and phase velocities of fundamental mode Rayleigh waves to obtain a vertically polarized 3-D shearwave velocity model (3DVSAM) of the crust and uppermost mantle of Mexico, the Gulf of Mexico and the Caribbean plate. We combine surface wave velocities from ANT and earthquake tomography. The model offers a picture of the seismic structure from 5 to $70 \mathrm{~km}$ depth of the region as a whole. Our model agrees with present and past tectonic processes in the region, coincides with crustal features showed in local studies, images with high detail the uppermost mantle, and exhibits some new seismological features. This model may be useful to constrain tectonic evolution models, localize regional earthquakes, simulate ground motions, and correct crustal effects in mantle tomography studies, among other possible applications.

The 3-D crustal and uppermost mantle shear-wave velocity model 3DVSAM is available to download at: https: //sites.google.com/site/earthsciencesbgaite.

Author contributions. B. Gaite designed and carried out the data processing. A. Villaseñor designed the research and collected the earthquake records. A. Iglesias developed the inversion code. I. Jiménez-Munt computed the gravity anomaly. All the authors interpreted the results. B. Gaite prepared the manuscript with contributions from the co-authors.

Acknowledgements. Seismic data come from the Mexican National Seismological Service (NSSM), and from the networks CI, CU, G, GE, II, IU, LI, NR, OV, TA and US through the IRIS Consortium. We acknowledge C. Valdés, A. Cárdenas, C. Cárdenas, I. Rodríguez, J. Pérez, J. Estrada, and S. I. Franco for providing NSSM data.

The maps and graphs were drawn with the Generic Mapping Tools (Wessel and Smith, 1998).

Funds provided by the REPSOL CO-DOS project supported B. Gaite. This is a contribution of the Team Consolider-Ingenio 2010 TOPO-IBERIA (CSD2006-00041). We thank D. García and A. Ugalde for their useful comments for improving this manuscript. We also are grateful to Taka'aki Taira and two anonymous reviewers for their constructive and helpful suggestions for enhancing the paper.

Edited by: T. Taira

\section{References}

Allan, J. F., Nelson, S. A., Luhr, J. F., Carmichael, I. S. E., Wopat, M., and Wallace, J. P.: Pliocene-Recent rifting in SW Mexico and associated volcanism: an exotic terrain in the making, AAPG Memoir, 47, 425-445, 1991.

Alsina, D., Woodward, R. L., and Snieder, R. K.: Shear wave velocity structure in North America from large-scale waveform inversions of surface waves, J. Geophys. Res., 101, 15969-15986, doi:10.1029/96JB00809, 1996.

Ammon, C. J.: Notes on surface-wave tomography. Part I: Group velocity estimation, p. 44, Unpublished Notes, 1998.

Aragón-Arreola, M. and Martín-Barajas, A.: Westward migration of extension in the northern Gulf of California, Mexico, Geology, 35, 571, doi:10.1130/G23360A.1, 2007.

Aragón-Arreola, M., Morandi, M., Martín-Barajas, A., DelgadoArgote, L., and González-Fernández, A.: Structure of the rift basins in the central Gulf of California: Kinematic implications for oblique rifting, Tectonophysics, 409, 19-38, doi:10.1016/j.tecto.2005.08.002, 2005.

Auer, L., Boschi, L., Becker, T. W., Nissen-Meyer, T., and Giardini, D.: Savani: A variable resolution whole-mantle model of anisotropic shear velocity variations based on multiple data sets, J. Geophys. Res., 119, 3006-3034, doi:10.1002/2013JB010773, 2014.

Barmin, M., Ritzwoller, M. H., and Levshin, A. L.: A fast and reliable method for surface wave tomography, Pure Appl. Geophys. 158, 1351-1375, 2001.

Bedle, H. and van der Lee, S.: $S$ velocity variations beneath North America, J. Geophys. Res., 114, B07308, doi:10.1029/2008JB005949, 2009.

Bensen, G. D., Ritzwoller, M. H., and Yang, Y.: A 3-D shear velocity model of the crust and uppermost mantle beneath the United States from ambient seismic noise, Geophys. J. Int., 177, 11771196, doi:10.1111/j.1365-246X.2009.04125.x, 2009.

Berteussen, K. A.: Moho depth determination based on spectral ratio analysis of NORSAR long-period P waves, Phys. Earth Planet. Inter., 31, 313-326, 1977.

Bijwaard, H. and Spakman, W.: Non-linear global P-wave tomography by iterated linearized inversion, Geophys. J. Int., 141, 71-82, 2000.

Bird, D. E., Burke, K., Hall, S. A., and Casey, J. F.: Gulf of Mexico tectonic history: Hotspot tracks, crustal boundaries, and early salt distribution, The American Association of Petroleum Geologists Bulletin, 89, 311-328, 2005.

Bird, P.: An updated digital model of plate boundaries, Geochem. Geophys. Geosyst., 4, 1027, doi:10.1029/2001GC000252, 2003.

Bozdağ, E. and Trampert, J.: On crustal corrections in surface wave tomography, Geophys. J. Int., 172, 1066-1082, doi:10.1111/j.1365-246X.2007.03690.x, 2008.

Burke, K.: Tectonic evolution of the Caribbean, Ann. Rev. Earth Planet. Sci., 16, 201-230, 1988.

Campillo, M., Singh, S. K., Shapiro, N. M., Pacheco, J. F., and Herrmann, R. B.: Crustal structure south of the Mexican volcanic belt, based on group velocity dispersion, Geofisica Internacional, 35, 361-370, 1996.

CGMW/UNESCO: Geological Map of the World at $1: 25$ million. Commission for the Geological Map of the World, UNESCO, second edition, September 2000. 
Cordoba-Montiel F., Iglesias, A., Singh, S. K., Spicka, Z. and Legrand, D: Tomografía de Velocidad de Grupo para el Oriente de México y el Istmo de Tehuantepéc, Bol. Soc. Mex., 66, 3, 441-457, 2014.

Couch, R. W., Ness, G. E., Sanchez-Zamora, O., Calderon-Riverol, G., Doguin, P., Plawman, T., Coperude, S., Huehn, B., and Gumma, W.: Gravity anomalies and crustal structure of the Gulf and Peninsular Province of the Californias, in: The Gulf and Peninsular Province of the Californias: American Association of Petroleum Geologists, Memoir, edited by: Dauphin, J. P. and Simoneit, B. R. T., 47-70, 1991.

Dickinson, W. R.: The Gulf of Mexico and the southern margin of Laurentia, Geology, 37, 479-480, doi:10.1130/focus052009.1, 2009.

Divins, D. L.: Total sediment thickness of the world's oceans and marginal seas, NOAA National Geophysical Data Cente, Boulder, CO, 2003.

Ferrari, L., Valencia-Moreno, M., and Bryan, S.: Magmatism and tectonics of the Sierra Madre Occidental and its relation with the evolution of the western margin of North America., in: Geology of Mexico: Celebrating the Centenary of the Geological Society of México: Geological Society of America Special Paper, edited by: Alaniz-Álvarez, S. A. and Nieto-Samaniego, A. F., 1-39, 2007.

Fullea, J., Fernández, M., and Zeyen, H.: FA2BOUG-A FORTRAN90 code to compute Bouguer gravity anomalies from gridded free air anomalies: Application to the AtlanticMediterranean transition zone, Comput. Geosci., 34, 1665-1681, doi:10.1016/j.cageo.2008.02.018, 2008.

Gaite, B., Iglesias, A., Villaseñor, A., Herraiz, M., and Pacheco, J. F.: Crustal structure of Mexico and surrounding regions from seismic ambient noise tomography, Geophys. J. Int., 188, 14131424, doi:10.1111/j.1365-246X.2011.05339.x, 2012.

Godey, S., Snieder, R. K., Villaseñor, A., and Benz, H. M.: Surface wave tomography of North America and the Caribbean using global and regional broad-band networks: phase velocity maps and limitations of ray theory, Geophys. J. Int., 152, 620-632, doi:10.1046/j.1365-246X.2003.01866.x, 2003.

Goffe, W. L.: SIMANN: A Global Optimization Algorithm using Simulated Annealing, Studies in Nonlinear Dynamics \& Econometrics, 1, 1558-3708, doi:10.2202/1558-3708.1020, 1996.

Goffe, W. L., Ferrier, G. D., and Rogers, J.: Global optimization of statistical functions with simulated annealing, Journal of Econometrics, 60, 65-99, doi:10.1016/0304-4076(94)90038-8, 1994.

Gomberg, J., Prietsley, K., and Brune, J.: The compressional velocity structure of the crust and upper-mantle of northern Mexico and the border region, Bull. Seism. Soc. Am., 79, 1496-1519, 1989.

González-Fernández, A., Dañobeitia, J. J., Delgado-Argote, L. A., Michaud, F., Córdoba, D., and Bartolomé, R.: Mode of extension and rifting history of upper Tiburón and upper Delfín basins, northern Gulf of California, J. Geophys. Res., 110, B01313, doi:10.1029/2003JB002941, 2005.

Grand, S. P.: Mantle shear structure beneath the Americas and surrounding oceans, J. Geophys. Res., 99, 11591-11621, doi:10.1029/94JB00042, 1994.

Handschy, J. W., Keller, G. R., and Smith, K. J.: The Oauachita system in northern Mexico, Tectonics, 6, 323-330, 1987.
Herrmann, R. B.: Computer programs in seismology, available at: http://www.eas.slu.edu/People/RBHerrmann/ ComputerPrograms.html (last access: 5 January 2014), St. Luis University, St. Luis, Missouri, 1987.

Iglesias, A., Cruz-Atienza, V. M., Shapiro, N. M., Singh, S. K., and Pacheco, J. F.: Crustal structure of south-central Mexico estimated from the inversion of surface-wave dispersion curves using genetic and simulated annealing algorithms, Geofísica Internacional, 40, 181-190, 2001.

Iglesias, A., Clayton, R. W., Pérez-Campos, X., Singh, S. K., Pacheco, J. F., García, D., and Valdés-González, C.: S wave velocity structure below central Mexico using high-resolution surface wave tomography, J. Geophys. Res., 115, B06307, doi:10.1029/2009JB006332, 2010.

Laske, G., Masters, G., Ma, Z., and Pasyanos, M.: Update on CRUST1.0 - A 1-degree Global Model of Earth's Crust, Geophys. Res. Abstracts, 15, Abstract EGU2013-2658, 2013.15, 2013.

Lekić, V., Panning, M., and Romanowicz, B. A.: A simple method for improving crustal corrections in waveform tomography, Geophys. J. Int., 182, 265-278, doi:10.1111/j.1365246X.2010.04602.x, 2010.

Levshin, A. L., Barmin, M. P., Ritzwoller, M., and Trampert, J.: Minor-arc and major-arc global surface wave diffraction tomography, Phys. Earth Planet. Inter., 149, 205-223, 2005.

Lin, F.-C., Moschetti, M. P., and Ritzwoller, M. H.: Surface wave tomography of the western United States from ambient seismic noise: Rayleigh and Love wave phase velocity maps, Geophys. J. Int., 173, 281-298, doi:10.1111/j.1365-246X.2008.03720.x, 2008.

Lizarralde, D., Axen, G. J., Brown, H. E., Fletcher, J. M., GonzálezFernández, A., Harding, A. J., Holbrook, W. S., Kent, G. M., Paramo, P., Sutherland, F. H., and Umhoefer, P. J.: Variation in styles of rifting in the Gulf of California, Nature, 448, 466-469, doi:10.1038/nature06035, 2007.

Londslade, P.: Geology and tectonic history of the Gulf of California, The Eastern Pacific Ocean and Hawaii (The Geology of North America, N), edited by: Husson, D., Winterer, E. L., and Decker, R. W., Geol. Soc. Am., Boulder, CO, 1989.

Luhr, J. F., Nelson, S. A., Allan, J. F., and Charmichael, I. S. E.: Active rifting in south-western Mexico: manifestations of an incipient eastward spreading ridge jump, Geology, 13, 54-57, doi:10.1130/0091-7613(1985)13<54:ARISMM>2.0.CO;2, 1985.

Marshall, J. S.: Geomorphology and physiographic provinces of Central America, in: Central America: Geology, resources and hazards, edited by: Bundschuh, J. and Alvarado, G., Taylor and Francis, London, 75-122, 2007.

McNamara, D. E., McCarthy J., and Benz H.: Improving earthquake and tsunami warning for the Caribbean Sea, Gulf of Mexico and the Atlantic coast, U.S. Geological Survey Fact Sheet, NO. 2006-3012, 4pp., 2006.

Melgar, D. and Pérez-Campos, X.: Imaging the Moho and subducted oceanic crust at the isthmus of Tehuantepec, Mexico, from receiver functions, Pure Appl. Geophys. 168, 1449-1460, doi:10.1007/s00024-010-0199-5, 2011.

Moreno, F. A., Mickus, K. L., and Keller, G. R.: Crustal structure and location of the Ouachita orogenic belt in northern Mexico, Geofísica Internacional, 39, 229-246, 2000. 
Müller, R. D., Sdrolias, M., Gaina, C., and Roest, W. R.: Age, spreading rates, and spreading asymmetry of the world's ocean crust, Geochem. Geophys. Geosyst., 9, Q04006, doi:10.1029/2007GC001743, 2008.

Nieto-Samaniego, A. F., Alaniz-Álvarez, S. A., and Camprubí í Cano, A.: La Mesa central de México: estratigrafía, estructura y evolución tectónica cenozoica, Boletín de la Sociedad Geológica Mexicana, Boletín Conmemorativo del Centenario, Temas Selectos de la Geología Mexicana, LVII, 285-318, 2005.

Oskin, M. and Stock, J. M.: Marine incursion synchronous with plate-boundary localization un the Gulf of California, Geology, 31, 23-26, doi:10.1130/00917613(2003)031<0023:MISWPB>2.0.CO;2, 2003.

Panning, M. P., Lekić, V., and Romanowicz, B. A.: Importance of crustal corrections in the development of a new global model of radial anisotropy, J. Geophys. Res., 115, 1-8, doi:10.1029/2010JB007520, 2010.

Pasyanos, M. E., Masters, G. T., Laske, G., and Ma, Z.: LITHO1.0: An updated crust and lithospheric model of the Earth, J. Geophys. Res.-Solid Earth, 119, 2153-2173, doi:10.1002/2013JB010626, 2013.

Persaud, P., Pérez-Campos, X., and Clayton, R. W.: Crustal thickness variations in the margins of the Gulf of California from receiver functions, Geophys. J. Int., 170, 687-699, doi:10.1111/j.1365-246X.2007.03412.x, 2007.

Pindell, J. and Kennan, L.: Tectonic evolution of the Gulf of Mexico, Caribbean and northern South America in the mantle reference frame: an update. The origin and evolution of the region between North and South America, Geological Society London Special Publication, 328, 1-55, 2009.

Poole, F. G., Perry Jr., W. J., Madrid, R. J., and Amaya-Martínez, R.: Tectonic synthesis of the Ouachita-Marathon-Sonora orogenic margin of southern Laurentia: Stratigraphic and structural implications for timing of deformational events and plate-tectonic model, Geological Society of America Special Paper, 393, 543596, doi:10.1130/0-8137-2393-0.543, 2005.

Ritsema, J., Van Heijst, H., and Woodhouse, J.: Global transition zone tomography, J. Geophys. Res., 109, 1-14, doi:10.1029/2003JB002610, 2004.

Ritzwoller, M. H., Shapiro, N. M., Barmin, M. P., and Levshin, A. L.: Global surface wave diffraction tomography, J. Geophys. Res., 107, 2335, doi:10.1029/2002JB001777, 2002.

Ritzwoller, M. H., Lin, F. C., and Shen, W.: Ambient noise tomography with a large seismic array, C. R. Geoscience, 343, 558-570, doi:10.1016/j.crte.2011.03.007, 2011.

Rogers, R. D, Mann, P., and Emmet, P. A.: Tectonic terraines of the Chortis block based on integration of regional aeromegnetic and geologic data, The Geol. Soc. of Am., Special Paper, 428, 65-88, doi:10.1130/2007.2428(04), 2007.

Sabra, K. G., Gerstoft, P., Roux, P., Kuperman, W. A., and Fehler, M. C.: Surface wave tomography from microseisms in Southern California, Geophys. Res. Lett., 32, L14311, doi:10.1029/2005GL023155, 2005.

Sandwell, D. T. and Smith, W. H. F.: Marine gravity anomalies from GEOSAT and ERS-1 satelite altimetry, J. Geophys. Res., 102, 10039-10054, doi:10.1029/96JB03223, 1997.

Sandwell, D. T., Müller, R. D., Smith, W. H. F., Garcia, E., and Francis, R.: New global marine gravity model from CryoSat-2 and Jason-1 reveals buried tectonic structure, Science, 346, 6567, doi:10.1126/science.1258213, 2014.

Schaeffer, A. J. and Lebedev, S.: Global shear-speed structure of the upper mantle and transition zone, Geophys. J. Int., 194, 417-449, doi:10.1093/gji/ggt095, 2013.

Schaeffer, A. J. and Lebedev, S.: Imaging the North American continent using waveform inversion of global and USArray data, Earth Planet. Sci. Lett., 402, 26-41, doi:10.1016/j.epsl.2014.05.014, 2014.

Sedlock, R. L.: Tectonoestratigraphic terranes and tectonic evolution of Mexico, Geological Society of America Special Paper, 278, 153 pp., 1993.

Shapiro, N. M. and Ritzwoller, M. H.: Monte-Carlo inversion for a global shear-velocity model of the crust and upper mantle, Geophys. J. Int., 151, 88-105, 2002.

Shapiro, N. M., Campillo, M., Paul, A., Singh, S. K., Jongmans, D., and Sánchez-Sesma, F. J.: Surface-wave propagation accross the Mexican Volcanic Belt and the origin of the long-period seismicwave amplification in the valley of Mexico, Geophys. J. Int., 128, 151-166, doi:10.1111/j.1365-246X.1997.tb04076.x, 1997.

Shapiro, N. M., Campillo M., Stehly L., and Ritzwoller, M. H.: High-resolution surface-wave tomography from ambient seismic noise, Science, 307, 1615-1618, doi:10.1126/science.1108339, 2005.

Siebert, L. and Simkin, T.: Volcanoes of the world: an illustrated catalog of Holocene volcanoes and their eruptions, http://www. volcano.si.edu (last access: 17 December 2014), 2002.

Swayer, D. S., Buffler, R. T., and Pilger, R. H. J.: Ther crust under the gulf of Mexico basin, in: The Geology of North America, edited by: Salvador, A., The Geological Society of America, 5372, 1991.

Trampert, J., Paulsen, H., van Wettum, A., Ritsema, j., Clayton, R. W., Castro, R., Rebollar, C. J., and Pérez-Verti, A.: New array monitors seismic activity near the Gulf of California in Mexico, Eos Trans. AGU, 84, 29-32, doi:10.1029/2003EO040002, 2003.

Van der Lee, S. and Nolet, G.: Upper mantle S velocity structure of North America, J. Geophys. Res., 102, 22815-22838, doi:01480227/97/97JB-01168, 1997.

Vdovin, O., Rial, J., Levshin, A. L., and Ritzwoller, M. H.: Groupvelocity tomography of South America and the surrounding oceans, Geophys. J. Int., 136, 324-340, doi:10.1046/j.1365246X.1999.00727.x, 1999.

Wang, Y., Forsyth, D. W., and Savage, B.: Convective upwelling in the mantle beneath the Gulf of California, Nature, 462, 499-501, doi:10.1038/nature08552, 2009.

Wessel, P. and W. H. F. Smith: New, improved version of Generic Mapping Tools released, Eos Trans. AGU, 79, 579, doi:10.1029/98EO00426, 1998.

Yang, Y. and Ritzwoller, M. H.: Teleseismic surface wave tomography in the western U.S. using the Transportable Array component of USArray, Geophys. Res. Lett., 35, L04308, doi:10.1029/2007GL032278, 2008.

Yao, H., Beghein, C., and van der Hilst, R. D.: Surface wave array tomography in SE Tibet from ambient seismic noise and two-station analysis - II. Crustal and upper-mantle structure, Geophys. J. Int., 173, 205-219, doi:10.1111/j.1365246X.2007.03696.x, 2008.

Zamora-Camacho, A., Espindola, V. H., Pacheco, J. F., Espindola, J. M., and Godinez, M. L.: Crustal thickness at the Tuxtla Volcanic 
Field (Veracruz, Mexico) from receiver functions, Phys. Earth Planet. Inter., 182, 1-9, doi:10.1016/j.pepi.2010.05.009, 2010.

Zhang, X. and Paulssen, H.: Geodynamics of the Gulf of California from surface wave tomography, Phys. Earth Planet. Inter., 192193, 59-67, doi:10.1016/j.pepi.2011.12.001, 2012.

Zhang, X., Paulssen, H., Lebedev, S., and Meier, T.: Surface wave tomography of the Gulf of California, Geophys. Res. Lett., 34, L15305, doi:10.1029/2007GL030631, 2007.
Zheng, Y., Shen, W., Zhou, L., Yang, Y., Xie, Z., and Ritzwoller, M.: Crust and upermost mantle beneath the north China Craton, northeast China, and the Sea of Japan from ambient noise tomography, J. Geophys. Res., 116, 1-25, doi:10.1029/2011JB008637, 2011.

Zhou, L., Xie, J., Shen, W., Zheng, Y., Yang, Y., Shi, H., and Ritzwoller, M. H.: The structure of the crust and uppermost mantle beneath South China from ambient noise and earthquake tomography, Geophys. J. Int., 189, 1565-1583, doi:10.1111/j.1365246X.2012.05423.x, 2012. 